\title{
АКТУАЛЬНІ ПРОБЛЕМИ ПУБЛІЧНОГО ТА ПРИВАТНОГО ПРАВА УКРАЇНИ
}

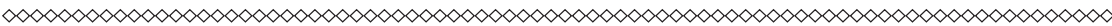

DOI https://doi.org/10.32837/app.v63i0.19

УДК 340.342

Дудченко В. В.* (НУ «ОЮА»)

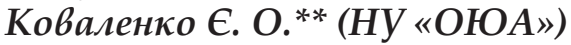

\section{ТЕНДЕНЦІЯ ВЗАСМОДІЇ СВІТСЬКОЇ ТА РЕЛІГІЙНОЇ СФЕР В ДЕЯКИХ КРАЇНАХ ПРЕЦЕДЕНТНОГО ПРАВА}

\section{TRENDS OF THE INTERACTION BETWEEN SECULAR AND RELIGIOUS SPHERES IN COMMON LAW COUNTRIES}

*Valentyna Dudchenko - Doctor of Laws, Professor, Department of General Theoretical Jurisprudence, National University "Odesa Law Academy" (23, Fontanska Doroha St., Odesa, Ukraine).

**Yelyzaveta Kovalenko - Master of Laws, National University "Odesa Law Academy" (23, Fontanska Doroha St., Odesa, Ukraine).

\section{Abstract}

The legal status of religions of different religious denominations, national guarantees of individual and collective freedom of conscience, faith and worship in some countries are analyzed. The most common problem in the case law countries are investigated; namely, in this article, North America is represented by the USA and Mexico, the Australian continent - by Australia, Asia - by the Philippines 
and India, Africa - by Tanzania. It has been found that a common feature of such countries is common law. It has been determined that these countries clearly follow the traditions of Anglo-American law.

It is found that most of the analyzed countries tend to borrow US experience in religious matters, which is an example of a modern democratic secular state. It is understood that no provision of the US Constitution can be construed to restrict the right of the United States or any of the States to publicly or ceremoniously pay tribute to the religious heritage, beliefs, and traditions of its people. The exercise by the people of their rights guaranteed by the First Amendment shall not lead to the establishment of a state religion.

It is determined that the most different from the US experience is the experience of Tanzania. The peculiarity of regulating the religious issue in this country determines an alliance with Zanzibar, because if the population of the continental part of the new republic is predominantly Christian (or professes local pagan beliefs), but the inhabitants of the island part are almost exclusively Muslims. Tanzania's new secular law has been found to be a compromise between monogamy and polygamy, which is able to reconcile the main Islamic demand for the recognition of polygamous marriages for the political purpose of promoting in Tanzania such families that are in line with modern understanding of freedom and equality.

The fundamental right of religious freedom is highlighted as one of the general principles of law and its constituent part. An approach to the religious phenomenon and churches as the embodiment of cultural identity and self-consciousness of nations, groups or minorities is substantiated by the authors.

Keywords: legal status of religions, national guarantees of freedom of conscience, faith and worship, common law, cultural identity and self-consciousness of nations.

Релігія, як в історичній ретроспективі, так і в сучасних умовах, $є$ важливим критерієм культурної ідентичності і самосвідомості народів, груп чи меншин. Ї̈̈ основне фундаментальне право індивідуальної і колективної релігійної свободи є одним із загальних принципів права. Визнання подібного засадничого зв'язку культури, релігії і права в сучасних умовах значно актуалізоване глобалізацій ними процесами в світі, міжнародним співробітництвом, свободою телекомунікації, затвердженням плюралізму цінностей. Усі ці чинники обумовлюють гостру необхідність порівняльного дослідження релігійного феномену.

Визначальним у даному дослідженні, на нашу думку, має стати усвідомлення того, що справжньою гарантією захисту основних прав 
людини, в тому числі і права на свободу релігійного сповідання, є не повноваження політичної влади, а глибинні пласти культури народів. Релігія є одним з таких пластів.

Порівняльне дослідження ролі релігії і права в зарубіжних країнах допомагає краще розуміти інші народи. Така зацікавленість виявляється тим сильнішою, чим менш схожа країна, що розглядається, на нашу власну, бодай це викликано відмінностями в правових i релігійних приписах чи в суспільних реаліях.

3 огляду на сказане, мета цієї статті полягає у тому, щоб проаналізувати правовий статус релігій, різних релігійних конфесій, гарантії індивідуальної і колективної свободи совісті, віри, культу та релігійних переконань в деяких країнах прецедентного права.

Для розгляду питань релігійного права вибрано низку таких країн. Для досягнення поставленої мети необхідно дослідити найбільш типові проблемні вузли в країнах прецедентного права, з якими в змозі зіштовхнутися дослідник неєвропейського права, а також низку цікавих фактів, якими деякі з цих країн в змозі нас здивувати. Таке дослідження пробуджує зацікавленість до вивчення питання про той вплив, який культура і релігія чинять на право в таких різних суспільствах.

Північна Америка представлена в нашій статті США і Мексикою, австралійський континент - однойменною Австралією, Азія Філіппінами і Індією, Африка - Танзанією. В усіх цих країнах панує common law (загальне право), і самі вони чітко дотримуються традиції англо-американського права.

Сполучені Штати Америки - найважливіша із не європейських країн. У сучасному світі американська система слугує взірцем західного суспільства. Прикладом США, як ми побачимо, в різний час надихалися країни із цілком різною історією і традиціями. Досвід США викликає особливу увагу на підставі низки причин. По-перше, принцип свободи віросповідання реалізується в США з урахуванням величезної різноманітності вірувань і конфесій, а також високого ступеня чутливості населення до цієї проблеми, як і взагалі до питання індивідуальної свободи. По-друге, американське суспільство і сьогодні залишається найбільш досконалою моделлю світської держави, втіленою в ідеї відокремленої держави від релігії. По-третє, діюча в США система common law є прецедентним правом, що нівелює можливість невідповідності формальних норм реальній судовій практиці (Брольо, Мирабелли, Онида, 2008, с. 308-311). 
Основи релігійної політики США були вперше сформульовані в американській Декларації незалежності (1776 р.) та Конституції (1791 р.). Наведемо фрагмент з Декларації незалежності: «Ми вважаємо ці істини самоочевидними і що вони наділені своїм Творцем певними невідчужуваними Правами, серед яких право на Життя, на Свободу і бажання Щастя». Відомий американський юрист і філософ права Лео Штраус вважає, що нація, віддана цій заяві, нині є найбільш могутньою і процвітаючою серед усіх націй Землі (Штраус, 2007, с. 3). Інший американський юрист і філософ права Джон Фінніс у своєму відомому трактаті «Природне право і природні права» відзначає, що девізом Оксфордського університету є «Dominus illuminatio mеа» - «Господь - має світло» (лат.) (Финнис, 2012, c. 14-15). 3 релігією проф. Дж. Фінніс пов' язує більш глибокий рівень пояснення індивіда і суспільства, влади, закону, прав, справедливості і обов'язку. 3 релігією зв' язана більш повна людська причетність благу. «Бог є безмежна, «абсолютна» цінність і єдність з Богом («релігія») - одна із основних людських цінностей» (Финнис, 2012, с. 502).

Перша поправка до Конституції США, вона ж - перша стаття Біля про права (як доповнення до Конституції) проголошує: «Конгрес не повинен видавати жодного закону, що стосується інституцій релігії чи забороняти вільне сповідання їй...». 14-а поправка до Конституції США проголошує: «...жоден штат не в змозі позбавляти будь-яку особу життя, свободи чи власності без належної правової процедури чи відмовляти будь-якій особі в межах своєї юрисдикції в рівному захисті закону». Зазначена поправка стосувалася і релігійної свободи як однієї із невід'ємних свобод, гарантом якої стає не тільки Конгрес, але і - безпосередньо перед громадянами - цілком вся держава, як федеральна влада, так і влада штату.

Оскільки американська судова система є прецедентною, то особливе значення в питаннях державного регулювання і релігійної свободи мають рішення Верховного суду США. В одній із своїх найважливіших постанов, суд проголосив «положення першої поправки про вільне сповідання встановлює повну заборону на державне втручання в релігійні переконання» і «..є надійним захистом для правомірної поведінки, продиктованої релігійними переконаннями» (Брольо, Мирабелли, Онида, 2008, с. 316).

В іншому рішенні Верховний Суд зробив фундаментальну заяву, яка проголосила, що «свобода вірити абсолютна, але свобода практикувати свою віру відносна і в змозі бути піддана обмеженням» 
(Брольо, Мирабелли, Онида, 2008, с. 313). Зусилля судової системи були спрямовані на те, щоб «уточнити межі», з урахуванням яких держава в змозі обмежити свободу «практикувати» віру. Верховний Суд вирішив, що релігійна свобода у правовий спосіб може бути обмежена чи цілком заборонена тільки тоді, коли вона представляє очевидну і справжню небезпеку для громадянського суспільства (Брольо, Мирабелли, Онида, 2008, с. 315). У разі, коли зіштовхнулися інтереси держави і релігії судді необхідною «зважити» кожний з них і зробити вибір на користь більш істотного і важливого.

Таким чином, релігійний інтерес стає предметом судової оцінки. На думку відомого італійського фахівця з релігійного права Франческо Оніда, це створює серйозну проблему оскільки має місце протиріччя з ідеєю відокремлення держави від релігії. Згідно $з$ цією ідеєю, державним органом відмовлено в праві оцінювати релігійний феномен (Брольо, Мирабелли, Онида, 2008, с. 315).

В 1980-х роках Верховний Суд знову став активним учасником релігійних процесів. Суд запропонував однозначну і кінцеву точку зору на використання критерію «зважування інтересів» при тлумаченні положення 1-ої поправки, яка забороняє Конгресу видавати закони, що порушують свободу совісті громадян. Були прийняті рішення, що обмеження релігійної свободи може бути виправдане, якщо державі вдається довести, що таке обмеження необхідне для здійснення фундаментального переважаючого суспільного інтересу.

США є країною класичного розуміння світської держави, коли релігійне життя регламентується тільки шляхом загального законодавства. Це означає відміну будь-якого законодавчого втручання в релігійні вірування і культові дії.

Законодавцю заборонено, як на федеральному рівні, так і на рівні штатів, не тільки встановлювати державну релігію чи надавати одній або декільком релігіям привілейованого статусу, але також і підтримувати «релігійність» як таку, порівняно з атеїстичними чи іншими ідеологічними переконаннями. Рішенням судів були відмінені в державних школах дві традиції, що були надзвичайно широко поширені і мали тривалу історію. Йдеться про традиції здійснювати на початку занять загальнохристиянську чи навіть загальнорелігійну молитву, а також традицію без будь-яких коментарів читати в класі невеликий уривок із Біблії.

3 іншого боку, було б глибокою помилкою розуміти ці заходи як прояв ворожості до феномену релігії. Навпаки, Верховному суду 224 
вдавалося примирити загальну релігійність американців з світськими уподобаннями ліберальної культури, проявляючи гнучкість і уникаючи крайніх суджень. Так, суди приймали рішення, що співпраця між державною школою і державою не суперечить ідеї світського суспільства: дітям дозволялося один раз на тиждень йти зі школи на годину раніше, щоб мати можливість навідувати уроки релігії в своїх церквах і храмах. Верховний Суд гарантував релігійним групам можливість користуватися навчальними закладами, призначеними для студентських заходів. Релігія, таким чином, отримала офіційно закріплений доступ в державні школи і університети (Брольо, Мирабелли, Онида, 2008, с. 332-337).

Підбиваючи підсумки, сенс і ступінь світськості американського суспільного устрою можна виразити наступним чином. Жодне положення Конституції не можна тлумачити так, щоб це обмежувало право Сполучених Штатів чи будь-якого із штатів виказувати публічно чи церемоніально данину поваги релігійному спадку, віруванням і традиціям свого народу. Здійснення народом своїх прав, гарантованих першою поправкою, не має привести до встановлення державної релігії (Брольо, Мирабелли, Онида, 2008, с. 354).

Мексика. 28 січня 1992 р. були оприлюднені поправки до ст. 3, 5, 24, 27, 130 федеральної Конституції 1917 р. і 16 липня цього ж року набрав чинності Закон про релігійні об'єднання і публічний культ. На думку мексиканських правників, реформа 1992 р. вперше в Мексиці окреслила звичну вже для Європи галузь права під назвою «релігійне право». Був започаткований перехід від антиклерикалізму ${ }^{1}$ до світськості.

Для більш глибокого розуміння сенсу і цінності мексиканського релігійного права необхідно порівняти його $з$ тим, що йому передувало.

Фундаментальні принципи Конституції 1917 р. такі. Стаття 24 проголошує сповідання релігії вільним в межах, дозволених кримінальним законодавством, і допускає публічну релігійну практику в храмах і приватну - в приватних домах.

Стаття 5 забороняє створення монастирських орденів; стаття 27 накладає суворі обмеження на правоздатність релігійних установ. Стаття 3 присвячена важливій темі викладення релігії в школах.

${ }^{1}$ Антиклерикалізм (від анти... i clericalis - церковний) - рух, спрямований проти клерикалізму, проти привілеїв церкви і духівництва. 
Згідно з цією статтею не тільки державні, але і приватні школи зобов' язані максимально дистанціюватися від будь-яких релігій.

Найбільш важлива конституційна норма виражена в статті 130, яка містить як загальні принципи, так і спеціальні норми стосовно релігії. Так, федеральній владі належить в галузі релігійного культу здійснювати втручання, передбачене законом. Мала місце низка обмежень, покликаних вберегти народ, державу, уряд від втручання релігії. Головним засобом стала повномасштабна дискримінація громадянських і політичних прав священників (тобто, фактично католицького духівництва).

Після Другої світової війни антиклерикальні настрої в мексиканському суспільстві починають слабшати, що дало змогу в 1979 р. організувати перше відвідування країни Папою Римським. Після цього почав зростати рівень релігійної терпимості в суспільстві, що дозволило започаткувати примирення з католицькою церквою.

Реформа 1992 р. мала такі наслідки. Стаття 24 Конституції вже не вимагала щоб релігійні культи здійснювалися виключно в приватних приміщеннях чи в церквах. Із статті 5 Конституції зникло положення про чернецькі вірування і обряди як джерела неприпустимого обмеження невід'ємних прав особистості і, таким чином, зникла заборона на організацію чернецьких орденів.

Стаття 27 Конституції повертає релігійним об'єднанням, установам на законних підставах правоздатність стосовно прав здобуття і володіння майном, необхідного для здійснення їхньої діяльності.

Серйозні зміни сталися і у відносинах між релігією і освітою. Оновлена стаття 3 Конституції підтвердила світський характер державної освітньої системи, як виключно наукової. Однак, ця модель вже не стосувалася приватних шкіл. Була скасована заборона священикам і релігійним об'єднанням брати участь в діяльності груп і організацій, що стосується початкової, середньої і вищої освіти.

Стаття 130 Конституції проголошує принцип виключної компетенції Конгресу стосовно релігії. Ст. 130 називає принципи, які були уточнені Законом про релігійні об'єднання і публічний культ. Ці принципи такі: а) релігійні об'єднання оформлюють запит, особливим чином реєструються (в реєстрі) і отримують статус юридичної особи; б) релігійні об'єднання отримують гарантії невтручання в їх справи; в) до призначення служителів усіх релігій висуваються вимоги цивільного характеру; г) служителі культу отримують право активного виборчого права. 
Мексиканські правники одноголосно підтримали цю реформу як надважливий крок у відмові від антиклерикалізму - наслідку революції, якій довелося боротися з церквою, що володіла усією економічною і політичною владою старого панівного класу - i, врешті, поновлення релігійної свободи.

Мексика, слідом за США, зорієнтована на класичне розуміння світської держави, в якій релігія і плюральна світська держава не втручаються в справи одна одної.

Австралія. Розділ 116 Конституції Австралії, що дуже нагадує 1-у поправку Біля про права США, забороняє державі як встановлювати офіційну релігію і примушувати громадян до дотримання тих чи інших релігійних приписів, так і обмежувати вільне сповідування будь-якої релігії. Окрім того, стаття забороняє вимагати в людини заяв стосовно іï релігійної віри як умови вступу на державну посаду. Останнє положення схоже з розділом 3 ст. VI Конституції Сполучених штатів.

Така схожість формування австралійської конституційної норми із історично передуючою їй нормою другої країни, також з системою common law, обумовлює те, що американський досвід вплинув і на історію тлумачення цих правових норм. Австралійська правова наука постійно посилається на американські прецеденти у цій галузі.

Розділ 116 австралійської Конституції розподіляє повноваження співдружності і штатів в питаннях релігії. Ці питання передаються в компетенцію австралійських штатів. Федеральні законодавчі органи позбавлені можливості регулювати релігійні питання для всіх громадян і не мають над ними прямої і безпосередньої влади. Це є однією із особливостей австралійської Конституції.

Релігійні питання також розглядаються на рівні судів австралійських штатів. Одним із важливих стало рішення про викладання релігійних дисциплін в державних школах штату Новий Південний Уельс (1976 р.). Суд штату проголосив правомірним запровадження в державних школах предмету католицької релігії з метою формування у дітей загальної культурної освіченості. Суд унеможливив законодавчу заборону практикувати молитву в класі, навіть коли в ній міститься чітке релігійне ствердження, наприклад про божественність Христа як Сина Божого. Таке викладання передбачає право не брати у ньому участі тим, хто цього не бажає (Брольо, Мирабелли, Онида, 2008, с. 374-376).

Філіппіни. Нова Конституція Філіппін прийнята 15 жовтня 1986 р. і ратифікована народним референдумом 2 лютого 1987 р. містить 
чимало норм стосовно релігії. В преамбулі Конституції проголошено відмову про допомогу до Господа Всемогутнього.

Як і у випадку з Австралією, має місце схожість із фундаментальним текстом 1-ї поправки Біля про права США. Конституційні норми про релігію в загальних рисах повторюють американські формулювання, вироблені при тлумаченні 1-ї поправки. Це стосується передусім звільнення релігійних об'єднань від сплати податків, заборони використання державних засобів на підтримку релігійних організацій і діячів (сюди входять викладачі релігії в державних школах, але не входять священики, які працюють в армії, виправних закладах, дитячих будинках). Може складатися враження, що філіппінська конституційна система не має особливостей в сфері регулювання релігійного питання, оскільки є, по суті, копією американського досвіду.

Однак, тенденцією в філіппінській Конституції є погашення заборони на встановлення релігії. Не дивлячись на підтвердження принципу світської держави, такі релігійні дати, як Воскресіння, Різдво, Великий четвер, Велика П'ятниця і 1 листопада є вихідними днями для усієї країни, бо вважається, що їх дотримання має благодійний моральний ефект для суспільства. Це стає зрозумілим, якщо зважити на релігійну історію філіппінського суспільства, а також важливу роль, яку національна Католицька церква відіграла в революції проти диктатури президента Маркоса. Церква не просто підтримала революцію, але і брала участь в написанні основного закону через своїх представників в Конституційній комісії. Тому в положеннях про економічне і громадське життя можна безпомилково виявити вплив соціальної доктрини Католицької церкви. Відданість католицьким ідеям ще більш виразно відображено в конституційних положеннях про захист законного шлюбу. На Філіппінах заборонене розлучення для усіх, окрім мусульман; не тільки аборт, але і подружня зрада $є$ злочином (Брольо, Мирабелли, Онида, 2008, с. 385-386).

Водночас, деякі племена і народності, які є «нехристиянськими», користуються низкою податкових пільг. Ця обставина задовольняє вимогам як принципу розподілу, так і принципу рівності (Брольо, Мирабелли, Онида, 2008, с. 383-384).

Принципу релігійної свободи присвячена ст. XIV філіппінської Конституції: «У випадку, якщо батьки чи опікуни письмово і однозначно висловлюються на користь викладання їх дитині релігії, таке викладання в змозі бути забезпечено як в початковій школі, так і 
на більш високих ступенях навчання в межах шкільного розкладу викладачами, призначеними чи погодженими релігійними органами тієї релігії, до якої належить учень». Гарантії релігійної свободи підкріплюються створенням системи стипендій, допомоги та інш. для учнів, які відзначилися або є малозабезпеченими, як з боку державних, так і приватних шкіл.

Індія. 3 усіх країн Індія є, напевно, найбільш загадковою і своєрідною для європейської свідомості і тому має для нас як значний інтерес, так і чималу складність в розумінні.

Суспільно-політичний устрій Індії грунтується на релігійних традиціях і культурі буддизму і джайнізму. Індуїстське суспільство є найбільш спіритуалістським у світі. Таке суспільство здатне наполягати на дотриманні суворих релігійних правил. Звідси гострі і конфліктні протиріччя між світськими і релігійними законами.

Індія, таким чином, стоїть перед вибором, пов'язаним із прагненням перетворити державу, яка пронизана релігійністю, у світську і який ще не був зроблений остаточно і однозначно.

Конституція, прийнята 26 листопада 1949 р., визначила Індію як суверенну демократичну республіку. Прийнята в 1976 р. 42-а поправка до конституції змінила це формулювання на суверенну світську демократичну республіку. Стаття 15 Конституції надає гарантії принципу рівності, проголошуючи незаконною будь-яку дискримінацію за релігійною, расовою, кастовою, статевою і національною ознаками.

Ст.ст. 25, 26, 27, 28, 29, 30 індійської конституції цілком присвячено питанням релігії. Найважливішою є ст. 25, яка проголошує: «При дотриманні громадського порядку, вимог моралі і здоров'я, всі особи володіють рівним правом на свободу совісті і правом сповідати, практикувати і поширювати релігію». На перший погляд, такий припис спрямований на забезпечення релігійної свободи, однак на практиці скоро з'ясувалося, що його новизна і вплив на суспільство полягали, навпаки, у тому, що вперше в історії індійського права міркування спільного блага офіційно визнавалися достатньою підставою для обмеження релігійної свободи. Ідея другорядності релігійної свободи стосовно суспільних потреб цілком революційна і відповідальність за ії майбутнє покладається на законодавця та на контроль і вплив судів, тим більше, що йдеться про таку судову систему, як common law. Суддя володіє досить значними повноваженнями в оцінці релігійного феномену (Брольо, Мирабелли, Онида, 2008, с. 391-402). 
Стаття 25 індійською конституції уточнює, що дана конституційна норма не забороняє законодавцю регулювати економічну, фінансову, політичну сторони діяльності, що має суспільне значення, в тому числі і діяльності релігійного характеру, і навіть прямо обумовлює можливість прийняття законів, спрямованих на обмеження чи скасування релігійних привілеїв які є частиною давньої традиції.

Водночас, якщо закон явно спрямований на утиски якоїнебудь конфесіï, іiі існування чи розширення або втручається в іï організаційно-управлінську діяльність, то відповідно до ст. 26 Конституції, суд має право визнати його неконституційним, таким, що наносить шкоду релігії.

Ст. 27 Конституції проголошує релігійну нейтральність держави через заборону державного фінансування церков. Жодну особу не можна примусити платити ніякі податки, призначені для оплати витрат на підтримку будь-якої релігії чи релігійної течії.

Згідно зі ст. 28 Конституції, ніяке навчання релігії не може мати місце в освітньому закладі, який повністю фінансується із державних фондів. При цьому держава має право надавати церквам податкові привілеї. У цій же ст. 28 додатково проголошується про можливість державного фінансування релігійних шкіл і викладання релігії в них за умови, що цей предмет не є обов' язковим для вивчення.

Ст.ст. 29 і 30 гарантуються право меншин на збереження мови, релігії і культури, в тому числі через організацію власних шкіл і управління ними (Брольо, Мирабелли, Онида, 2008, с. 406-407).

Танзанія. Сьогодні ця країна $є$ типовою державою африканського континенту, чого не можна сказати про жодну із середземноморських і інших ісландських держав Африки, ні тим більше про Південну Африку, яка є абсолютним винятком як з економічної, так i історично-політичної точок зору. Ці держави заслуговують на самостійне дослідження.

Танзанія виникла як держава в 1964 р. вона була спершу німецькою, а потім англійською колонією (звідси система common law i англійська мова, яка поділяє статус державної із мовою суахілі). Республіка Танзанія є союзом із Занзібаром, який був у складі Султана Оман, потім був під протекторатом Англії і, нарешті, в 1963 р. також отримав незалежність. Саме цей союз обумовлює своєрідність в регулювання релігійного питання, бо якщо населення континентальної частини нової республіки переважно християнське (або 
сповідує місцеві язичницькі вірування), то жителі острівної частини (Занзібар і Петбо) майже виключно мусульмани.

В Танзанії діє конституція, сучасна редакція якої була прийнята в 1977 р. 15 березня 1988 р. у якості додатку до конституції набув чинності Біль про права, який більш чітко і детально регулює права громадян. Дотримання конституційної законності контролює Верховний Суд. Рішення суду є джерелами права, що цілком узгоджується із системою common law.

Ст. 3 Конституції Об'єднаної Республіки Танзанія вимагає від уряду і всіх державних установ гарантувати «...рівні можливості для всіх громадян, як чоловіків, так і жінок, без поділу за кольором, расою, племенем і віросповіданням...». Ця гарантія рівності повторюється і доповнюється в ст. 13. Статті 12-32 Конституцій є Білем про права. Стаття 18 гарантує всім громадянам свободу думки, право на вільний пошук інформації про життя країни. Пункт 1 ст. 19 забезпечує свободу совісті і вибору в питаннях релігії, а пункт 2 гарантує свободу здійснення культу і свободу релігійної пропаганди, а також оговорює, що подібна діяльність мусить розглядатися як особиста справа індивіда i, таким чином, позбавляє представників держави будь-яких повноважень стосовно діяльності релігійних груп. Раніше в Танзанії обмеженням була піддана низка релігійних груп, які вважалися небезпечними для інтересів держави, це, передусім, Свідки Ієгови і Скінія Сіона.

Після прийняття Біля про права загальне ставлення до феномену релігії в Танзанії стає більш «західним». Правління Джуліуса H'єрері - першого президента Танзанії і одного з кращих постколоніальних лідерів в Африці - завжди було пронизано духом свободи і світськості. Тож, прагнучи розділити дві сфери, держава обмежує свою владу стосовно релігійних груп. Держава стимулює ці групи податковими пільгами і дозволяє займатися викладанням різних релігій в державних школах (гарантуючи водночас учням право відмовитися від відповідних занять).

Нове світське право Танзанії є компромісом між моногамією і полігамією. Цей компроміс здатний примирити головну ісламську вимогу (тут відчувається приєднання до союзу Занзібара) про визнання полігамних шлюбів з політичною метою стимулювати в Танзанії такі шлюби і сім'ї, які відповідають сучасним уявленням про свободу і рівність (Брольо, Мирабелли, Онида, 2008, с. 411-416). 
В результаті проведеного дослідження доходимо до висновку, що спільною рисою розглянутих країн $є$ common law (загальне право); ці країни виразно дотримуються традиції англо-американського права. У цій традиції суди наділені широкими дискримінаційними повноваженнями при розгляді конфліктних ситуацій у сфері релігійного права.

Правовий статус релігій зорієнтований на сучасні міжнародні стандарти. У міжнародному праві опрацьоване нове, широке поняття «культура» згідно з яким воно охоплює релігійні переконання і переконання ідеологічного характеру. Релігія, як історично, так і сьогодні, $\epsilon$ важливим критерієм культурної ідентичності і самосвідомості народів, груп чи меншин.

Основне і фундаментальне право індивідуальної і колективної релігійної свободи є одним із загальних принципів права і його складовою частиною.

Фундаментальну перспективу подальшого опрацювання обраної проблеми утворюють такі напрямки як компаративна методологія в релігійному праві, феномен релігії і юридичних системах Близького і Далекого Сходу, а також Південної Африки, сучасні домінуючі тенденції у реалізації норм релігійного права.

\section{Лimepamypa:}

Брольо Ф., Мирабелли Ч., Онида Ф. (2008). Религии и юридические системы. Пер. с ит. М.: Библейно-богословский институт св. апостола Андрея.

Финнис Дж. (2012). Естественное право и естественные права. Пер. с англ. М., ИРИСЭН, Мысль.

Штраус Л. (2007). Естественное право и история. М.: Водолей Publishers.

\section{References:}

Brolo F., Mirabelli Ch., Onida F. (2008). Religii i yuridicheskie sistemyi [Religions and legal systems]. Per. s it. M.: Bibleyno-bogoslovskiy institut sv. apostola Andreya. [in Russian].

Finnis Dzh. (2012). Estestvennoe pravo i estestvennyie prava [Natural law and natural rights]. Per. s angl. M., IRISEN, Myisl. [in Russian].

Shtraus L. (2007). Estestvennoe pravo $i$ istoriya [Natural law and history]. M.: Vodoley Publishers. [in Russian]. 


\section{Анотація}

Дудченко В. В., Коваленко Є. О. Тенденція взаємодії світської та релігійної сфер $b$ деяких крайнах прецедентного права. - Стаття.

Проаналізовано правовий статус релігій різних релігійних конфесій, національні гарантії індивідуальної і колективної свободи совісті, Віри і культу в деяких країнах, спільною рисою яких є соттоп lаш (загальне право) і що изі країни виразно тримаються традиції англо-американського права.

Основне і фундаментальне право релігійної свободи висвітлено як одне iз загальних принципів права і його складової частини. Обгрунтовано підхід до релігійного феномену і церков як до втілення культурної ідентичності і самосвідомості народів, груп чи меншин.

Ключові слова: правовий статус релігій, національні гарантії свободи cobicmi, віри і культу, соттоп lаw, культурна ідентичність і самосвідомість народів. 